\title{
A Rare Case Caused by Bartonella henselae in Northern Cyprus: Cat Scratch Disease
}

\author{
Kuzey Kıbrıs’ta Bartonella henselae'nın Neden Olduğu Nadir Bir Olgu: Kedi Tırmığı Hastalığı
}

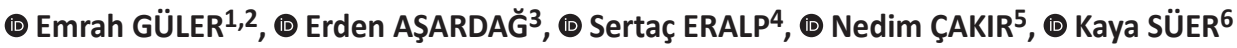 \\ ${ }^{1}$ Near East University, Faculty of Health Sciences, Department of Nutrition and Dietetics, Nicosia, Cyprus \\ 2 Near East University, DESAM Institute, Nicosia, Cyprus \\ 3 Private Practice, Internal Medicine Specialist, Nicosia, Cyprus \\ 4 LETAM Radiology Center, Nicosia, Cyprus \\ ${ }^{5}$ Near East University Faculty of Medicine, Department of Medical Microbiology and Clinical Microbiology, Nicosia, Cyprus \\ ${ }^{6}$ Near East University Faculty of Medicine, Department of Infectious Diseases and Clinical Microbiology, Nicosia, Cyprus
}

\section{Abstract}

Cat scratch disease (CSD) is a zoonotic infection caused by the bacteria of Bartonella henselae, which is transmitted to humans as a result of scratching or biting by cats, the source of the disease in nature. The disease is usually mild, but sometimes low fever and lymphadenopathy (LAP) at the site of the scracth can be seen. In our study, a 34-year-old female patient who applied to our hospital with bilateral groin pain and LAP in the inguinal region and was diagnosed with CSD is presented. Bartonella henselae immunoglobulin (Ig) G and Bartonella henselae IgM tests were performed with the indirect fluorescent antibody method on the patient, who had a kitten at home and had a scracthing history. Since both tests were positive and her history was compatible with CSD, $100 \mathrm{mg}(2 \times 1)$ dose of doxycycline was administered to our patient for 14 days and recovery was observed. While most CSD patients recover without treatment, some may develop complications. A good anamnesis and clinical examination in diagnosis can prevent unnecessary invasive procedures and high costs with many unnecessary laboratory tests. In conclusion, CSD should not be ignored in patients with regional LAP and a history of cat scracth.

Keywords: Bartonella henselae, Cat scratch disease, North Cyprus, rare

\section{Öz}

Kedi tırmığı hastalığı (KTH), Bartonella henselae bakterisinin neden olduğu, hastalığın doğadaki kaynağı olan kedilerin tırmalaması veya ısırması sonucu insanlara bulaşan zoonotik bir enfeksiyondur. Hastalık genellikle hafif seyretmekte fakat bazen düşük ateş ve tırmık yerinde lenfadenopati (LAP) ile izlenmektedir. Çalışmamızda, hastanemize inguinal bölgede bilateral kasık ağrısı ve LAP ile başvurup, KTH tanısı alan 34 yaşındaki kadın olgu sunulmuştur. Evinde yavru bir kedi besleyen ve tırmalama hikayesi bulunan hastaya indirekt floresan antikor yöntemiyle Bartonella henselae immünoglobulin (lg) G ve Bartonella henselae lgM testleri yapılmıştır. Her iki testin de pozitif çıkması ve öyküsünün KTH ile uyumlu olmasından dolayı, hastamıza $100 \mathrm{mg}(2 \times 1)$ dozunda doksisiklin 14 gün boyunca uygulandı ve iyileşme görüldü. Kedi tırmığı hastalığı hastalarının çoğu tedavi almadan iyileşebilmekte iken, bazılarında komplikasyonlar gelişebilmektedir. Tanıda iyi bir anamnez ve klinik muayene, gereksiz invazif girişimlerin ve çok sayıda gereksiz laboratuvar testleri ile yüksek maliyetlerin önüne geçebilmektedir. Sonuç olarak, bölgesel LAP izlenen ve kedi tırmığı hikayesi bulunan hastalarda KTH mutlaka göz ardı edilmemelidir.

Anahtar Kelimeler: Bartonella henselae, Kedi tırmığı hastalığı, Kuzey Kıbrıs, nadir

Cite this article as: Güler E, Aşardağ E, Eralp S, Çakır N, Süer K. A Rare Case Caused by Bartonella henseale in Northern Cyprus: Cat Scratch Disease. Mediterr J Infect Microb Antimicrob. 2021;10:16. 


\section{Introduction}

Cat scratch disease (CSD) is a zoonotic infectious disease caused by the microaerophilic, intracellular, Gram-negative bacillus Bartonella henselae. The disease can be transmitted to humans as a result of scratching or biting by cats, which are the source of the disease in nature, and it can be observed in all age groups, although it is frequently seen in children and young adults ${ }^{[1,2]}$. Studies have shown that the disease is also transmitted by a lice or tick bite ${ }^{[3]}$.

Bartonella henselae can present with a wide range of clinical symptoms including Parinaud oculoglandular syndrome, endocarditis, meningoencephalitis and fever of unknown origi $\mathrm{i}^{[4]}$. In addition, CSD is characterized by low fever, tender lymphadenopathy (LAP) that develops in 1-3 weeks, and papule or pustule at the scratching site. The disease is usually mild and self-limiting ${ }^{[5]}$. Generally, axillary and cervical lymph nodes are involved and involvement often occurs unilaterally ${ }^{[6]}$. Eye infections, severe muscle pain or encephalitis are rare symptoms of the disease $\mathrm{e}^{[7]}$.

In our study, a female patient who was admitted in our hospital with bilateral groin pain and was diagnosed as having CSD was presented.

\section{Case Report}

A 34-year-old female patient was examined in the gynecology outpatient clinic with a complaint of palpable LAP in the bilateral inguinal region. There was no finding to explain the inguinal LAP in the gynecological examination. When the C-reactive protein test was found to be $6.56 \mathrm{mg} / \mathrm{dl}$, the physician recommended the patient to be followed up. The patient, whose follow-up was recommended, was admitted to a different gynecologist, and bilateral multiple LAPs larger than $1 \mathrm{~cm}$ in size were detected in ultrasonography (USG). Lymphadenopathys were painful, stiff and mobile. The patient, who did not receive any treatment, was admitted to an internal medicine specialist due to pain in the bilateral inguinal area and increased sensitivity in the lymph nodes at the end of the fifth day. While cytomegalovirus (CMV) immunoglobulin ( $\mathrm{lg}$ ) G, toxoplasma IgG and Epstein-Barr virus (EBV) IgG tests were found to be positive; CMV IgM, toxoplasma IgM, EBV IgM, and anti-HIV tests were found to be negative. On repeated USG, there were LAPs the largest of which were $17 \times 12 \mathrm{~mm}$ and $16 \times 8 \mathrm{~mm}$ in size on the right femoral region, and $17 \times 11 \mathrm{~mm}$ and $16 \times 9 \mathrm{~mm}$ in size on the left femoral region (Figure 1). There were also LAPs which were $22 \times 14 \mathrm{~mm}$ in size near the left external iliac artery and $17 \times 9 \mathrm{~mm}$ in size near the right external iliac artery, with significantly thickened cortexes. Especially in two lymph nodes, the internal structure was roughly heterogeneous and increased vascularization with hilus entry was observed on color Doppler examination. There was patchy increased echogenicity in the adipose tissue around the LAPs. Especially on the left, it was noteworthy that the inflammation increased compared with the previous examination and that thin tubular and folded hypoechoic areas developed around a large lymph node, extending to the subcutaneous structure (Figure 2). The anamnesis of the patient was asked again and it was learned that she was feeding a kitten at her home and had been exposed to multiple cat scratches approximately 1.5 months ago. Thereupon, serum sample of the patient was taken for parietal cell antibody and Bartonella henselae $\lg \mathrm{M}$ and $\lg \mathrm{G}$ tests. While parietal cell antibody was negative, Bartonella henselae IgM was detected as positive at 1/100 titer (reference range: Negative) and Bartonella henselae $\lg \mathrm{G}$ as positive at 1/320 titer (reference range: Negative). During this time, the patient did not have fever and weight loss. In line with all the data, our patient was administered doxycycline at a dose of 100 $\mathrm{mg}$ (twice a day) for 14 days with the diagnosis of CSD and clinical improvement was achieved.

\section{Discussion}

The most common clinical symptom caused by Bartonella henselae is CSD. Subfebrile fever and unilateral sensitive regional LAP are seen in patients with typical CSD. The course of the disease is generally mild and self-limiting. Most of the patients have a history of direct contact with cats ${ }^{[8]}$. In

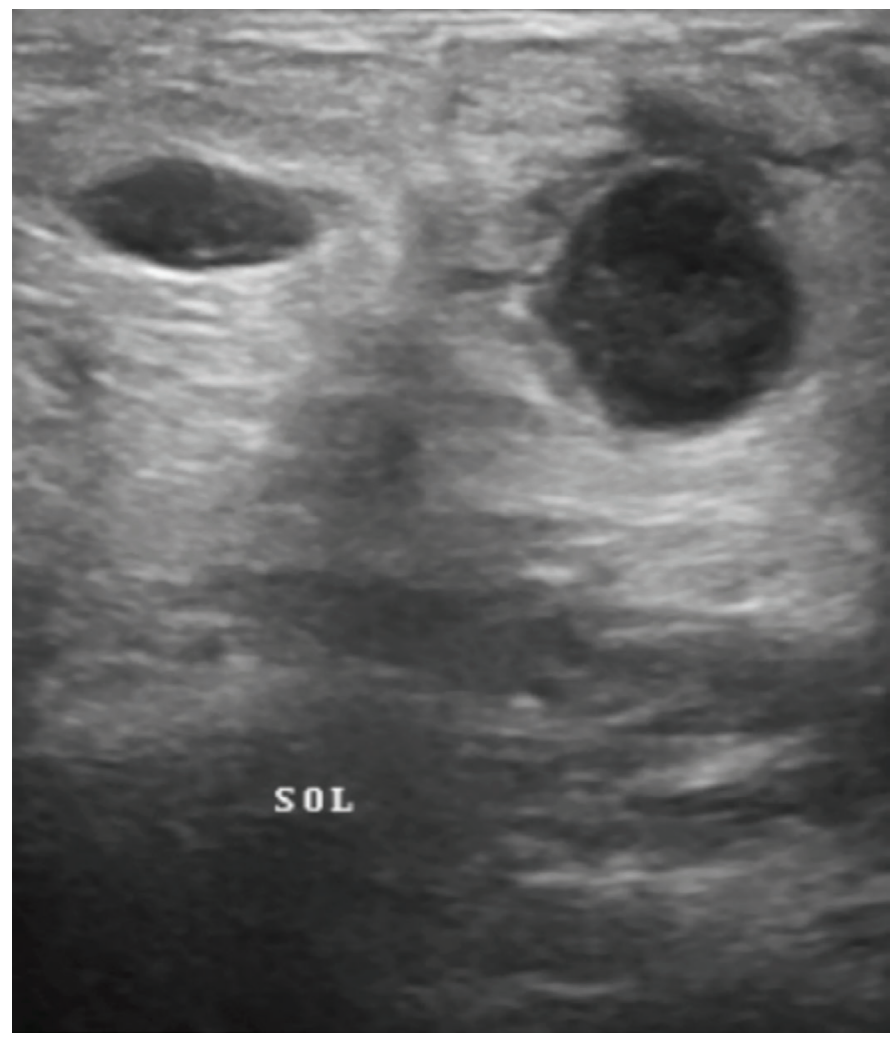

Figure 1. Lymphadenopathies in the left femoral region 
the transmission of the agent to humans, cats are seen as reservoirs in nature, and transmission to humans can usually be indirectly by cat scratches, bites and sometimes by cat fleas $^{[2]}$. The frequency of Bartonella henselae in healthy cats ranges between $25-41 \%{ }^{[9]}$. In a study investigating pathogens in cats in Cyprus, Bartonella henselae was found in 10.9\% of the cats ${ }^{[10]}$. Disease symptoms are generally not observed in cats. Since kittens can carry this agent in their blood for months, people who come into contact with kittens are at risk $^{[9]}$. Generally, it is reported that $90-95 \%$ of the patients have contact with cats ${ }^{[11]}$. In our patient, there was also a story of cat scratching and it was understood that the complaints started with multiple LAPs in the inguinal region approximately 45 days after the scratching.

Cat scratch disease, is generally seen sporadically in Turkey ${ }^{[2]}$. In a serological study conducted by Yilmaz et al. ${ }^{[12]}$ in healthy blood donors, Bartonella henselae seropositivity was found as $6 \%$. Bartonella henselae IgG seropositivity was found with a rate of 3.3\% in blood donors in the province of Aydın ${ }^{[13]}$. Akgün et al. ${ }^{[6]}$ encountered CSD in a 12-year-old male patient with inguinal LAP. In another study, it was reported that two adult male patients were diagnosed as having CSD. One of these patients had complaints of swelling in the axilla and the other in the groin ${ }^{[2]}$. In addition, patients with ocular involvement due to CSD were also reported. In a study in which 10 patients with ocular involvement were examined, it was found that nine of these patients had a cat scratch history. Bartonella henselae

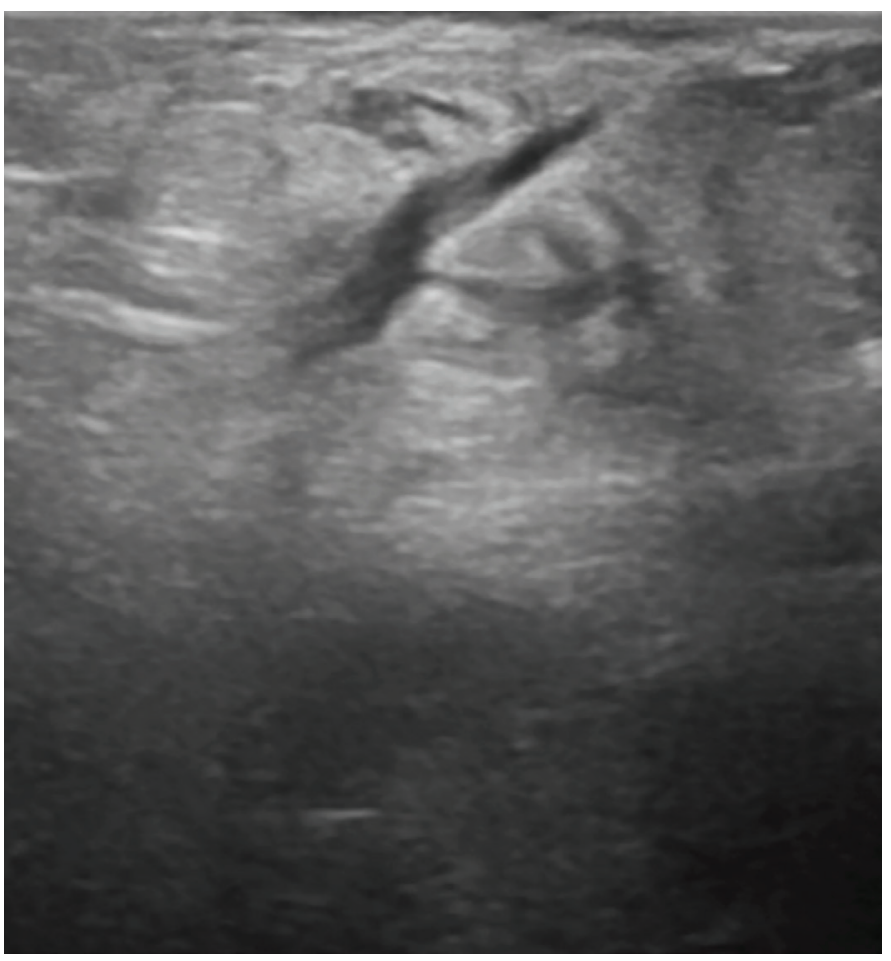

Figure 2. Tubular and folded hipoechoic structures seen under the skin in the inguinal region $\lg \mathrm{G}$ and/or IgM were positive in all patients ${ }^{[11]}$. In the literature, no case report of CSD was found reported in Northern Cyprus.

Pyogenic bacterial infections (retrocecal appendicitis, osteomyelitis, pyogenic arthritis, skin infections, urinary tract infections), tuberculosis, plague, genital herpes, syphilis, chancroid, granuloma inguinale, Iymphogranuloma venorum, tularemia and CSD are diseases that cause inguinal LAP. They should be kept in mind in differential diagnosis. Besides, inguinal LAPs can be observed in infections such as Entamoeba histolytica or Salmonella spp., and in malignancies such as Hodgkin lymphoma, non-Hodgkin lymphoma and acute leukemias. Cat scratching or cat-dog bite in the patients' history is a strong clue for the differential diagnosis of $\mathrm{CSD}^{[6]}$.

In the past, the detection of Bartonella henselae infection was only made by bacterial culture, tissue biopsyand histopathological examination of lymph nodes. However, isolation of Bartonella species in culture is very difficult due to a long incubation period (two-six weeks). In addition, isolating the bacteria gives unsuccessful results because systemic symptoms are generally not observed in patients. It is not considered effective to use only clinical symptoms in diagnosis. In recent years, the diagnosis of Bartonella infections has been made by serological methods based on the search for antibodies in the patient's serum and molecular techniques for searching for Bartonella DNA in the tissue. Serological methods are seen as the most practical methods because there is no invasive sample collection and the use of special equipment ${ }^{[3]}$. In addition, the fact that culture and other isolation methods are time consuming and difficult makes serological methods more advantageous. Generally, IFA and enzyme-linked immunosorbent assay methods are used to detect antibodies against Bartonella. In particular, the sensitivity of the IFA test is reported to be $84-88 \%$ and its specificity 94-96\%. In the diagnosis of CSD in humans, serological tests, especially IFA, are accepted as reference tests ${ }^{[14]}$. Antibody determination by serological methods is important for acute infection. IgM positivity indicates acute infection, but IgM can be detected in the blood up to approximately 100 days after exposure. This short time means that IgM can only be detected in $50 \%$ of infected patients. IgG antibodies against Bartonella henselae remain positive until 22-28 weeks after inoculation. Since $\operatorname{lgG}$ can remain in $25 \%$ of the patients, it is difficult to distinguish between old infection and acute infection ${ }^{[15]}$. In the study of Allizond et al. ${ }^{[16]}$, it was suggested that the diagnosis of CSD could be made more accurately by using real-time polymerase chain reaction (rt-PCR) and IFA methods. In another study conducted with samples taken from cats, it was reported that the combination of blood culture, nested-PCR and IFA tests gave the most accurate result in the diagnosis of Bartonella henselae infection ${ }^{[17]}$. Both Bartonella henselae IgG and IgM IFA tests performed in the serum of our patient were found to be 
positive, and the diagnosis was made with radiological results and clinical symptoms.

While most of the patients with CSD recover without treatment, complications may develop in some ${ }^{[18]}$. Erythromycin, doxycycline or azithromycin treatment is appropriate in patients who do not have an additional systemic disease such as immunodeficiency or diabetes. In addition, trimethoprim/sulfamethoxazole, quinolones or aminoglycosides are considered as alternative treatment options. It is emphasized that doxycycline treatment is used most frequently in patients with ocular involvement and it is used in combination with quinolone, macrolide and/or rifampicin in most of the patients ${ }^{[11]}$. Studies have shown that doxycycline and gentamicin provide a high level of treatment success in patients with CSD with suspected bacteremia ${ }^{[19]}$. In addition, penicillins, tetracyclines, cephalosporins, and aminoglycosides are other antibiotic options used against Bartonella infections. Especially, aminoglycosides with bactericidal effect are the first choice antibiotics in the treatment of Bartonella infections other than CSD. Generally, combined use of more than one antibiotic is recommended in severe infections ${ }^{[18]}$. Combined gentamicin/doxycycline therapy is recommended for the treatment of endocarditis, which is one of the important disorders caused by Bartonella hensela $\mathrm{e}^{[20]}$. In children diagnosed as having CSD $(<45.5 \mathrm{~kg})$, it is considered appropriate to use $10 \mathrm{mg} / \mathrm{kg}$ azithromycin once a day and 5 $\mathrm{mg} / \mathrm{kg}$ for the following four days ${ }^{[18]}$. Doxycycline treatment was given to our patient for 14 days and improvement was observed.

\section{Conclusion}

In our country, tests for the diagnosis of CSD, a rare infection caused by Bartonella henselae, are not performed. For this reason, unnecessary invasive procedures can be performed on patients and patients may face high costs with many unnecessary diagnostic tests. A good history and physical examination is an important step in diagnosis. Searching for Bartonella henselae $\lg \mathrm{G}$ and $\lg \mathrm{M}$ antibodies among serological tests, especially by IFA method, should be applied in the diagnosis of CSD. It has been observed that the use of doxycycline in treatment gives successful results. In conclusion, CSD should not be ignored in patients with regional LAP and a history of cat contact.

\section{Ethics}

Informed Consent: Consent form was filled out by all participants.

Peer-review: Externally and internally peer-reviewed.

\section{Authorship Contributions}

Surgical and Medical Practices: E.A., S.E., K.S., Concept: E.G., N.Ç., K.S., Design: N.Ç., K.S., Data Collection or Processing: E.A.,
S.E., K.S., Analysis or Interpretation: E.G., N.Ç., K.S., Literature Search: E.G., K.S., Writing: E.G.

Conflict of Interest: No conflict of interest was declared by the authors.

Financial Disclosure: The authors declared that this study received no financial support.

\section{References}

1. Canneti B, Cabo-López I, Puy-Núñez A, Garcia García JC, Cores FJ, Trigo M, Suárez-Gil AP, Rodriguez-Regal A. Neurological presentations of Bartonella henselae infection. Neurol Sci. 2019;40:261-8.

2. Uluğ M, Aslan V, Arık D, Yılmaz N, Üstün M. İki Kedi Tırmığı Hastalığı Olgusu: Nadir Görülen Zoonotik Bir İnfeksiyon Hastalığı. Klimik Dergisi. 2014;27:7881.

3. Congli Y, Caixia Z, Xiuguo H. Bartonella henselae infection and its effects on human health. Reviews in Medical Microbiology. 2011;22:67-72.

4. Favacho AR, Roger I, Akemi AK, Pessoa AA Jr, Varon AG, Gomes R, Godoy DT, Pereira S, Lemos ER. Molecular identification of Bartonella henselae in a seronegative cat scratch disease patient with AIDS in Rio de Janeiro, Brazil. Rev Inst Med Trop Sao Paulo. 2014;56:363-5.

5. Durey A, Kwon HY, Im JH, Lee SM, Baek J, Han SB, Kang JS, Lee JS. Bartonella henselae infection presenting with a picture of adult-onset Still's disease. Int J Infect Dis. 2016;46:61-3.

6. Akgün M, Belet N, Karlı A, Ceyhan Bilgici M, Sensoy G. Visseral Yayılım ve Inguinal Lenfadenopati: Nadir Bir Kedi Tırmığı Hastalığı Olgusu. J Pediatr Inf. 2012;6:109-11.

7. Centers for Disease Control and Prevention. Bartonella Infection (Cat Scratch Disease, Trench Fever, and Carrion's Disease), Symptoms. Available from: https://www.cdc.gov/bartonella/symptoms/index.html

8. Maritsi DN, Zarganis D, Metaxa Z, Papaioannou G, Vartzelis G. Bartonella henselae Infection: An Uncommon Mimicker of Autoimmune Disease. Case Rep Pediatr. 2013;2013:726826.

9. Bölük G, Mıstık R, Helvacı S, Yalçınkaya U, Öztürk Nazlıoğlu H. Azitromisinle Tedavi Edilen Muhtemel Üç Kedi Tırmığı Hastalığı Olgusu. FLORA. 2011;16:135-8.

10. Attipa C, Papasouliotis K, Solano-Gallego L, Baneth G, Nachum-Biala $Y$ Sarvani E, Knowles TG, Mengi S, Morris D, Helps C, Tasker S. Prevalence study and risk factor analysis of selected bacterial, protozoal and viral, including vector-borne, pathogens in cats from Cyprus. Parasites \& Vectors. 2017:10:130.

11. Oray M, Önal S, Koç Akbay A, Tuğal Tutkun I. Diverse Clinical Signs of Ocular Involvement in Cat Scratch Disease. Turk J Ophthalmol. 2017;47:9-17.

12. Yilmaz C, Ergin C, Kaleli I. Investigation of Bartonella henselaeseroprevalence and related risk factors in blood donors admitted to Pamukkale University Blood Center. Mikrobiyol Bul. 2009;43:391-401.

13. Aydin N, Bülbül R, Tellı M, Gültekın B. Seroprevalence of Bartonella henselae and Bartonella quintana in blood donors in Aydin province, Turkey. Mikrobiyol Bul. 2014;48:477-83.

14. Erinç SM. Kedilerde Bartonella henselae ve Bartonella clarridgeiae Prevalansının Araştırılması. Adnan Menderes Üniversitesi, Sağlık Bilimleri Enstitüsü, Mikrobiyoloji Anabilim Dalı. Yüksek Lisans Tezi, Aydın; 2015.

15. Mazur-Melewska K, Jończyk-Potoczna K, Mania A, Kemnitz P, Szydłowski J, Służewski W, Figlerowicz M. The significance of Bartonella henselae bacterias for oncological diagnosis in children. Infect Agent Cancer. 2015;10:30.

16. Allizond V, Costa C, Sidoti F, Scutera S, Bianco G, Sparti R, Banche G, Dalmasso P, Cuffini AM, Cavallo R, Musso T. Serological and molecular detection of 
Bartonella henselae in specimens from patients with suspected cat scratch disease in Italy: A comparative study. PLoS One. 2019;14:0211945.

17. Diren Sıgırcı B, Celik B, Basaran Kahraman B, Gumus B, Metiner K, Adıguzel MC, İkiz S, Bagcigil AF, Ozgur NY, Ak S. A Comparative Study on Detection of Bartonella henselae Infection by Culture Followed by PCR, Nested-PCR and IFA. Kafkas Univ Vet Fak Derg. 2017;23:333-7.

18. Centers for Disease Control and Prevention. Bartonella Infection (Cat Scratch Disease, Trench Fever, and Carrion's Disease). For Healthcare
Providers. Treatment. Available from: https://www.cdc.gov/bartonella/ clinicians/index.html

19. Prutsky G, Domecq JP, Mori L, Bebko S, Matzumura M, Sabouni A, Shahrour A, Erwin PJ, Boyce TG, Montori VM, Malaga G, Murad MH. Treatment outcomes of human Bartonellosis: a systematic review and meta-analysis. Int J Infect Dis. 2013;17:811-9.

20. Angelakis $E_{1}$ Raoult D. Pathogenicity and treatment of Bartonella infections. Int J Antimicrob Agents. 2014;44:16-25. 